\title{
New Intrinsically Thermostable Xylanase Improves Broilers' Growth Performance, Organ Weights, and Affects Intestinal Viscosity and $\mathrm{pH}$
}

\author{
Veerle Van Hoeck ${ }^{1, *}$, Georgios A. Papadopoulos ${ }^{2}{ }^{\circledR}$, Ilias Giannenas ${ }^{3}{ }^{\oplus}$, Styliani Lioliopoulou ${ }^{2}$, \\ Vasilios Tsiouris ${ }^{4}\left(\mathbb{D}\right.$, Tilemachos Mantzios ${ }^{4}$, , Konstantinos Kiskinis ${ }^{4}$ (D), Ioannis Grivas ${ }^{5}$, \\ Antonio Luis Gonzalez Sanchez ${ }^{1}$, Bindhu Lakshmibai Vasanthakumari ${ }^{1}$, Paschalis Fortomaris ${ }^{2} \mathbb{D}$ \\ and Dany Morisset ${ }^{1}$ (D)
}

1 Kemin Europa N.V., Animal Nutrition and Health EMENA, Toekomstlaan 42, 2200 Herentals, Belgium; antonioluis.gonzalez@kemin.com (A.L.G.S.); b.l.vasanthakumari@kemin.com (B.L.V.); dany.morisset@kemin.com (D.M.)

2 Laboratory of Animal Husbandry, Faculty of Veterinary Medicine, Aristotle University of Thessaloniki, 54124 Thessaloniki, Greece; geopaps@vet.auth.gr (G.A.P.); slioliopo@vet.auth.gr (S.L.); fortomap@vet.auth.gr (P.F.)

3 Laboratory of Animal Nutrition, Faculty of Veterinary Medicine, Aristotle University of Thessaloniki, 54124 Thessaloniki, Greece; igiannenas@vet.auth.gr

check for updates

Citation: Van Hoeck, V.;

Papadopoulos, G.A.; Giannenas, I.; Lioliopoulou, S.; Tsiouris, V.;

Mantzios, T.; Kiskinis, K.; Grivas, I.; Gonzalez Sanchez, A.L.;

Vasanthakumari, B.L.; et al. New Intrinsically Thermostable Xylanase Improves Broilers' Growth

Performance, Organ Weights, and Affects Intestinal Viscosity and $\mathrm{pH}$. Agriculture 2021, 11, 1235. https:// doi.org/10.3390/agriculture11121235

Academic Editors: Vito Laudadio and Vincenzo Tufarelli

Received: 8 November 2021

Accepted: 2 December 2021

Published: 8 December 2021

Publisher's Note: MDPI stays neutral with regard to jurisdictional claims in published maps and institutional affiliations.

Copyright: (c) 2021 by the authors Licensee MDPI, Basel, Switzerland. This article is an open access article distributed under the terms and conditions of the Creative Commons Attribution (CC BY) license (https:// creativecommons.org/licenses/by/ $4.0 /)$
4 Avian Unit, Faculty of Veterinary Medicine, Aristotle University of Thessaloniki, 54124 Thessaloniki, Greece; biltsiou@vet.auth.gr (V.T.); mantzios@vet.auth.gr (T.M.); kiskinik@vet.auth.gr (K.K.)

5 Laboratory of Anatomy, Histology and Embryology, School of Veterinary Medicine, Aristotle University of Thessaloniki, 54124 Thessaloniki, Greece; janos@vet.auth.gr

* Correspondence: veerle.vanhoeck@kemin.com

\begin{abstract}
Exogenous carbohydrases are commonly added to monogastric animal feed to degrade non-starch polysaccharides (NSP) to improve zootechnical performance and nutrient digestion. In the current study, the effects of dietary supplementation of a new, intrinsically thermostable, monocomponent xylanase on intestinal parameters, zootechnical performance and carcass traits of broilers were evaluated. A total of 720 1-day-old broilers were randomly allotted to four wheatbased diets with different levels of xylanase (T1: control; T2: 30,000 U/g; T3: 45,000 U/g; T4: $90,000 \mathrm{U} / \mathrm{g}$ ) and fed from 1 to 35 days of age. The data showed that xylanase supplementation reduced the intestinal viscosity significantly, especially in the ileum. Duodenum and cecum $\mathrm{pH}$ was not influenced by xylanase supplementation, while T3 treatment showed the lowest $\mathrm{pH}$ value in jejunum and ileum. Xylanase supplementation reduced significantly feed conversion ratio (FCR) without affecting feed intake (FI). T2 treatment exhibited a higher body weight gain (BWG) compared the other treatments. Live weight, carcass weight, legs, and liver weight were significantly higher in T3 and T4 treatments compared to T1. No significant differences on foot pad lesions were observed among the four treatments. In conclusion, dietary supplementation of this new xylanase significantly improves intestinal tract viscosity and affects beneficially broilers' performance and carcass traits.
\end{abstract}

Keywords: new xylanase; efficacy; intestinal viscosity; broiler; performance

\section{Introduction}

Reducing costs of feed production is a challenging issue for the poultry industry. Due to the increase in grain prices, the animal feed industry has been working towards lowering nutritional costs [1]. Due to shortage of corn supply and the increase of corn price, wheat has become an important source of energy in poultry diets because of. However, the utilization efficiency of wheat is lower than that of corn because it contains more anti-nutritive factors, especially non-starch polysaccharides (NSP). Wheat contains arabinoxylans, which are the major NSP fractions. The latter reduce the digestibility of nutrients and decrease 
the feed efficiency and growth performance when fed to poultry, especially in broiler chickens [2-4]. The anti-nutritive effect of NSPs is instigated by the increase of the viscosity of the intestinal digesta [5-8]. This increase in digesta viscosity jeopardizes nutrient bioavailability and decreases metabolizable energy which lowers the overall performance of animals fed on wheat-based diets $[9,10]$. Moreover, dietary NSP can also facilitate small intestinal fermentation by modulating the intestinal microflora [11,12], which might be detrimental to nutrient digestion and absorption for chickens [13].

Poultry have no production of endogenous carbohydrases capable of hydrolyzing the pentosan NSPs, such as the arabinoxylans, present in viscous cereals. Therefore, dietary supplementation of exogenous enzymes has proven to be a state-of-the-art cost-saving mechanism [1]. Exogenous enzymes can hydrolyze NSP, which improves the digestibility and utilization of nutrients. Xylanases are the major enzymes involved in arabinoxylan degradation, hydrolyzing the 1,4- $\beta$-D-xylosidic linkage between xylose residues in the backbone in a random manner [14]. Xylanase has been widely added to commercial wheat-based compound feeds for broilers and it is believed that these enzymes break down polysaccharide cage structures around proteins. The use of exogenous enzymes such as xylanase is a key component of broiler diets for efficient utilization of feed ingredients, down-grading production costs and improvement of performance indexes [1].

It is well documented that addition of NSP hydrolyzing enzymes to cereal-based diets is one of the major strategies to improve growth performance and nutrient digestion in broiler chickens. Supplementing feed with xylanase has been shown to improve nutrient digestibility and concomitantly preserve good gut health by allowing fewer nutrients to be available in the animal's gut for the potential growth of disease-causing bacteria [15-18]. This supplementation facilitates animal performance, with improved absorption of feed components and a greater efficiency in meat and egg production [19-21]. Furthermore, previous studies have demonstrated that addition of xylanases in wheat-based diets can reduce the intestinal viscosity by partially hydrolyzing NSPs of wheat. The latter results in improvements in nutrient digestibility and growth performance of broilers [22-24]. Moreover, other studies showed that xylanase supplementation of a wheat-based diet improved chicken immunity [23], reduced detrimental effect after Salmonella Typhimurium infection [25], or alleviated the intestinal mucosal barrier impairment of broiler chickens challenged by Clostridium perfringens [26].

A recently developed enzyme (Xygest ${ }^{\mathrm{TM}} \mathrm{HT}$ ) is a thermostable xylanase produced by Thermopolyspora flexuosa (Pichia yeast) and is a beta 1-4, endo-xylanase enzyme. Its use has been investigated in corn-based diets, which resulted in improved broiler performance and nutrient digestibility and promoted Lactobacilli growth [27]. However, no information is available so far on its efficacy in wheat-based diets. Based on the described effects of xylanases in wheat enriched broiler diets, it was hypothesized that the latter thermostable one could improve broiler growth performance, carcass yield, reduce intestinal viscosity and $\mathrm{pH}$ and influence positively foot pad dermatitis scoring when supplemented at different levels. The objective of the present study was to evaluate the efficacy of the new thermostable xylanase produced by Thermopolyspora flexuosa (Pichia yeast) in wheatbased broilers' diets, when supplemented at 30,000 U/g $(10 \mathrm{~g} / \mathrm{t}), 45,000 \mathrm{U} / \mathrm{g}(15 \mathrm{~g} / \mathrm{t})$, and $90,000 \mathrm{U} / \mathrm{g}(30 \mathrm{~g} / \mathrm{t})$.

\section{Materials and Methods}

\subsection{Xylanase Product}

Xygest $^{\mathrm{TM}}$ HT (Kemin Animal Nutrition and Health, Herentals, Belgium) is an intrinsically thermostable, monocomponent xylanase produced by Thermopolyspora flexuosa expressed in Pichia pastoris and is a beta 1-4, endo-xylanase enzyme belonging to the GH11 family, designed to improve the degradation of dietary fiber to maximize the energy utilization of the diet. Xygest HT has a minimum activity of 3,000,000 U/g on a corn starch-based carrier; the doses, expressed in $\mathrm{g} / \mathrm{t}$, correlate with the enzyme activity $(\mathrm{U} / \mathrm{kg})$ depicted in Table 1. 
Table 1. Trial design and dosages of the efficacy trials performed in broilers.

\begin{tabular}{|c|c|c|c|c|c|}
\hline Duration (Days) & $\begin{array}{l}\text { Number of } \\
\text { Treatments }\end{array}$ & $\begin{array}{c}\text { Replicates per } \\
\text { Treatment/Broilers } \\
\text { per Replicate/Total } \\
\text { Number of Broilers }\end{array}$ & Breed and Sex & $\begin{array}{c}\text { Intended Dose } \\
\text { (g/ton Xygest HT) }\end{array}$ & $\begin{array}{c}\text { Intended Dose } \\
\text { (U/kg) }\end{array}$ \\
\hline 35 & $\begin{array}{c}4 \\
(\mathrm{~T} 1, \mathrm{~T} 2, \mathrm{~T} 3, \mathrm{~T} 4)\end{array}$ & $12 / 15 / 720$ & $\begin{array}{l}\text { Ross 308, as } \\
\text { hatched }\end{array}$ & $\begin{array}{l}\text { T1: } 0 \\
\text { T2: } 10 \\
\text { T3: } 15 \\
\text { T4: } 30\end{array}$ & $\begin{array}{c}\text { T1: } 0 \\
\text { T2: } 30,000 \\
\text { T3: } 45,000 \\
\text { T4: } 90,000\end{array}$ \\
\hline
\end{tabular}

\subsection{Animals and Housing}

The procedures related to animal care used in this study were approved by Ethical Committee branch of the Research Committee of Aristotle University of Thessaloniki (decision number 811/21-01-2020; project code 99821). Animals were reared and treated in compliance with the Directive 2010/63/EU covering the protection of the animals used for experimental or other scientific purposes.

The study took place in a designated poultry house in the area of Galatista located in Chalkidiki prefecture of Greece. The premises belong to Strikos Poultry Enterprises, a company collaborating with the Laboratory of Animal Husbandry of the University of Thessaloniki and are used for experimental purposes under the license of the Greek Veterinary Authority. Broiler chicks were obtained from a commercial hatchery (Koutsos-Tzotzas Hatchery, $20 \mathrm{~km}$ of Thessaloniki-Poligiros National Road, Thessaloniki, 57006, Greece) and were orally vaccinated for Gumboro disease (CEVAC TRANSMUNE), Infectious Bronchitis (CEVAC MASS L; CEVAC IBIRD) and Newcastle Disease (CEVAC UNI L). Each pen was provided with one individual plastic feeder $(40 \mathrm{~cm}$ diameter in basis, $15 \mathrm{~kg}$ maximum capacity, with a capacity of up to 70 broilers based on manufacturer's recommendations) and one bell-type drinker (with a capacity of up to 100 broilers). In each pen ( $2.0 \mathrm{~m}$ length; $1.0 \mathrm{~m}$ width; $1.0 \mathrm{~m}$ height; basic material wooden beams and plastic wire), 15 mixed sex broilers were allocated, corresponding to a stocking density of 7.5 broilers $/ \mathrm{m}^{2}$. The facility room had window inlets in each two sides to control day length and entrance of physical light. Heating was provided by a gas heating system comprised of multi-zone installation of brooders using a thermostat placed at the center of the room. Ventilation was controlled by a semi-automated system by opening window inlets and function of mixing fans. Lighting program was managed according to Aviagen lightning recommendations. Specifically, a long day length of $23 \mathrm{~h}$ light and $1 \mathrm{~h}$ dark in the early stages of growth-up to 7 days of age was provided. Then according to recommendations, a minimum $4-6 \mathrm{~h}$ of darkness was provided from 7 days of age onwards. Temperature and humidity of the poultry house were daily monitored during the experiment.

\subsection{Experimental Design}

Seven hundred and twenty (720) one-day old mixed sex broiler chickens (Ross 308) were randomly allocated to four (4) dietary treatments comprised 12 pens each (48 pens in total). Broilers were not blocked for allocation to treatments either based on weight or sex (males, females). Each pen comprised one replicate. The experimental setup is presented in Table 1.

\subsection{Diets}

The diets were fed for a total period of 35 days and were provided in three phases as starter, grower, and finisher mash. The starter diets were fed from 0-14 days, the grower diets from 15-28 days, and the finisher diets from 29-35 days. Diet 1 (T1) consisted of a control diet. Diet 2 (T2) consisted of the control diet with $10 \mathrm{~g} / \mathrm{t}$ Xygest HT. Diet 3 consisted of the control diet supplemented with $15 \mathrm{~g} /$ ton Xygest HT. The last diet (T4) was the control diet plus $30 \mathrm{~g} /$ ton Xygest HT. All birds were fed ad libitum. All groups received the same basal compound feed, which was mainly based on corn, wheat, and soybean meal as in 
the control treatment. Table 2 shows the ingredients used in the study and the calculated nutrient content during the three phases of the study. All diets were manufactured before the onset of the experiment. The experimental feeds were manufactured at the feed mill of Strikos Poultry Enterprises. To avoid contamination between treatments, feeds without the test feed additive were prepared before feeds supplemented with the new xylanase (lot number 190703, produced at CRVAB, Chifeng, China). The latter were based on the control diets and were made in increasing concentrations. The basal feeds were produced with no xylanase, no antibiotics, no anti-coccidian drug or coccidiostats. Water was available for the chickens ad libitum. Except for the test product, the animals did not receive any other similar product for the whole study period.

Table 2. Composition of the diets; ingredients \% used in the studies and the calculated nutrient content.

\begin{tabular}{cccc}
\hline Ingredient & Starter & Grower & Finisher \\
\hline Corn & 15.0 & 10.0 & 10.0 \\
Soybean Meal 46\% & 32.6 & 28.1 & 20.8 \\
Wheat & 41.4 & 49.1 & 55.0 \\
Rapeseed meal & 4.0 & 5.0 & 6.0 \\
Soybean oil & 3.4 & 4.7 & 5.5 \\
MCP & 0.7 & 0.5 & 0.3 \\
Limestone & 1.4 & 1.2 & 1.1 \\
Lysine HCl & 0.3 & 0.3 & 0.3 \\
DL-Methionine & 0.4 & 0.3 & 0.3 \\
L-Threonine & 0.2 & 0.1 & 0.1 \\
L-Valine & 0.06 & 0.01 & 0.03 \\
NaCl & 0.2 & 0.2 & 0.2 \\
Sodium Bicarbonate & 0.2 & 0.2 & 0.2 \\
Mineral-Vitamin Premix & 0.3 & 0.3 & 0.3 \\
Ronozyme HiPhos (Phytase) & 0.02 & 0.02 & 0.02 \\
Total & 100.0 & 100.0 & 100.0 \\
Provision & $(\%)$ & $(\%)$ & $(\%)$ \\
AME poultry AVIAGEN, (Kcal/kg) & 2949.9 & 3049.8 & 3150.2 \\
\hline
\end{tabular}

At the ILVO institute in Belgium, diets were characterized (data presented in Table 3) by the following approach: NSP = 100-moisture-crude protein-crude fat-crude ash-starchsugar. Then, as the NSP are a heterogenic fraction, composed from cell membranes and pectines, these two fractions were separated by determination of Neutral Detergent Fiber (NDF). NDF is a factor for all cell membrane fractions. Then, by the calculation of NSP minus NDF, an indication of the pectines can be obtained. The fraction of the cell membranes was then split in hemicellulose, cellulose, and lignin by Acid Detergent Fiber (ADF) and Acid Detergent Lignin (ADL) determination. The difference between NDF and $\mathrm{ADF}$ is hemicellulose and the difference between ADF and ADL is a measure for cellulose.

\subsection{Measurements}

\subsubsection{Enzyme Activity Recovery in Feed Samples}

Feed samples from each treatment were provided to Kemin Europa N.V. for recovery of xylanase. More specifically, for the determination of the xylanase activity in feed, a slightly modified version of a commercially available test kit (xylazyme AX Tablets from Megazyme International Ireland) was used. Xylazyme AX tablets, containing dye-labelled cross-linked wheat xylan polymer as a substrate for enzymatic action, were suspended in aqueous feed extracts. The extracts were incubated with the xylazyme tablets at $\mathrm{pH}$ 4.8 using a citrate-phosphate buffer for $15 \mathrm{~min}$ at $50^{\circ} \mathrm{C}$. The xylan was hydrolyzed by the xylanase present in the extract, liberating color into the solution. The content of xylanase is finally determined by colorimetry at $585 \mathrm{~nm}$ using a calibration curve prepared with feed 
samples supplemented with a reference xylanase enzyme of known activity, available from the Applicant upon request, undergoing a similar procedure.

Table 3. Substrate characterization in the control diet.

\begin{tabular}{cc}
\hline Ingredient & Amount (\%) \\
\hline Moisture & 9.61 \\
Crude protein & 18.04 \\
Crude fat & 5.63 \\
Crude ash & 13.50 \\
starch & 35.24 \\
Sugars & 3.64 \\
NDF & 9.23 \\
ADF & 5.09 \\
ADL & 0.94 \\
NSP & 14.34 \\
Hemicellulose & 4.14 \\
Cellulose & 4.15 \\
\hline
\end{tabular}

\subsubsection{Visualization of Hydrolysis Products of Wheat Bran}

Chromatographic analysis of the in vitro reaction products of xylanase on wheat bran was performed using thin layer chromatography (TLC). Enzyme $(20 \mathrm{U} / \mathrm{mL})$ and wheat bran $(1 \%)$ were mixed and incubated for $30 \mathrm{~min}$ at $\mathrm{pH} 3.0$ by $40^{\circ} \mathrm{C}$. Then, the mixture was incubated for $2 \mathrm{~h}$ at $\mathrm{pH} 6.8$ by $40^{\circ} \mathrm{C}$, followed by a boiling and centrifugation step. The reaction mixture $(0.01 \mathrm{~mL})$ was applied on silica gel plates $(\mathrm{G}-60,10 \times 15 \mathrm{~cm})$ and subjected to two sequential ascending chromatography runs using 3:2:1 ( $v / v)$ ethyl acetate: acetic acid: water as the solvent system. After air drying the plate, spots developed by spraying with a solution of $0.5 \%$ thymol in $95 \%$ ethanol $+5 \mathrm{~mL}$ concentrated sulfuric acid. XOS (X2-X4) standards and AXOS (A3X,XA3XX/XA2XX) standards were used for detection.

\subsubsection{Viscosity and $\mathrm{pH}$ of Intestinal Digesta}

The homogeneous content of the jejunum and the ileum, from each bird were filled in separate laboratory tubes $(15 \mathrm{~mL})$. The tubes with homogeneous content from each anatomical part of intestine per bird were centrifuged at $3000 \times \mathrm{g}$ for $45 \mathrm{~min}$ in order to separate the feed particles from the liquid phase. Supernatants $(0.5 \mathrm{~mL})$ from each tube were taken and the viscosity was measured in a Brookfield LDV-II+ PRO Digital Viscometer (Brookfield Engineering Laboratories, Stoughton, MA, USA). Two readings were taken from each tube and were represented in units of centipoise (cP). The digesta of the duodenum, jejunum, ileum, and cecum from each bird were immediately collected in separate tubes $(15 \mathrm{~mL})$ and vortexed, in order to obtain a homogenous content from each anatomical part of intestine per bird. The $\mathrm{pH}$ of the duodenum, jejunum, ileum, and cecum from each bird was measured using a digital pH-meter ( $\mathrm{pH} 315 \mathrm{i}$, WTWWissenschaftlichTechnischeWerkstätten, Weilheim, Germany).

\subsubsection{Performance}

Zootechnical performance parameters were recorded throughout the experimental period. All birds were weighed on a pen basis at 1, 7, 14, 21, 28, and 35 days of age. Feed consumption per pen was estimated for the day intervals 1-7, 8-14, 15-21, 22-28, and 29-35. The average body weight (BW; g), average daily gain (BWG; g), average daily feed intake (ADFI; g) and feed conversion ratio (FCR; $g$ feed/g gain) were calculated for periods 1-7 days, 8-14 days, 15-21 days, 22-28 days, 29-35 days and for the overall study (1-35 days). Bird health was examined daily in the pens and any variation in appearance and/or behavior was recorded. Mortality was monitored daily. The animals that died or were culled during the study ( 9 for T1, 10 for T2, 1 for T3, 9 for T4) were weighed and necropsied by a veterinary pathologist within $12 \mathrm{~h}$ after death/culling. 


\subsubsection{Carcass Measurements and Internal Organ Weights}

At the end of the trial (D35), birds were randomly selected from each pen (replication) and were selected, euthanized, and directly taken to perform the following measurements: carcass yield, breast meat yield, weight of the abdominal fat pad, weight of the liver, weight of the heart, weight of the gizzard, weight of the kidney, weight of the bursa, weight of the thymus, and weight of the spleen. In total $n=24$ per treatment for live weight, carcass weight, breast, legs, liver, heart, gizzard, and intestine; whereas $n=12$ per treatment for kidneys, bursa of Fabricius, spleen, and thymus birds. The relative weight of internal organs was calculated as a ratio by dividing the organs weight by the birds live body weight $(\mathrm{g} / \mathrm{kg}$ of body weight).

\subsubsection{Foot Pad Lesion Scoring}

At day 35 of the experiment, the foot pad area was evaluated after taking pictures of birds' left and right feet. Here, 12 birds per treatment were evaluated. The lesions were scored with a 1-5 foot pad dermatitis scale based on the scoring scales described by Kaukonen et al. (2016) [28]. Specifically, the foot pads were scored as follows: score 1: no lesion-healthy foot pad; score 2: small $(\leq 1 \mathrm{~cm})$ superficial single or several small superficial lesions; score 3: large ( $>1 \mathrm{~cm})$ mild, superficial lesion; score 4: Small, severe, and deep lesions with dark crust and loss of papilla structure; score 5: Large $(>1 \mathrm{~cm})$, severe lesions with dark crust and loss of papilla structure. Afterwards, the extend of foot pad lesions was quantified. Both foot pads from all broilers were photographed from the same distance. On every digital photograph two areas of interest (AOI) were measured with the use of the image analysis software ImageJ [29], delineating the surface corresponding to a. the metatarsal pad, the first digital pads of the second, third, and fourth toes, and the lateral and intermediate interdigital webs (Figure 1A), b. the lesion (Figure 1B). Subsequently the ratio (quotient) of lesion area to the paw area was calculated and registered.
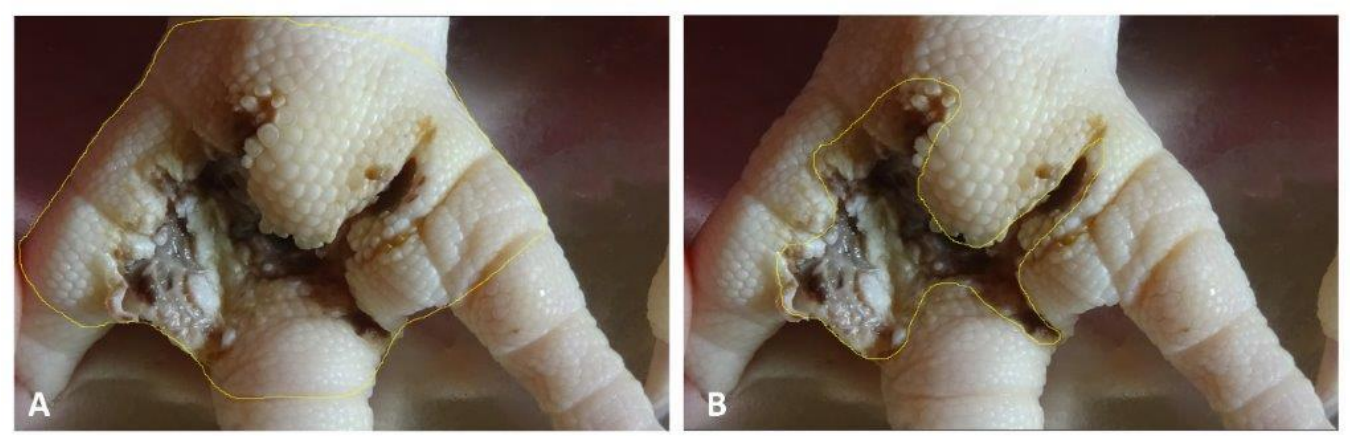

Figure 1. Images of chicken paw on which area of interest (AOI) delineating the surface corresponding to (A) the metatarsal pad, the first digital pads of the second, third and fourth toes, and the lateral and intermediate interdigital webs and (B) the lesion are shown.

\subsection{Statistical Analysis}

The pen (replicate) was the experimental unit. Each treatment had 12 pens (with 15 chickens per pen). Performance parameters were evaluated per pen (replicate). For carcass measurements and internal organ weights, each broiler was the experimental unit. The effect of dietary treatments on performance parameters of broilers in the present study was analyzed with one-way ANOVA using SPSS 25.0 (BM SPSS Statistics for Windows, Version 25.0. Armonk, NY, USA: IBM Corp.). The dietary treatment groups were included as fixed factors in the statistical model. Post-hoc comparisons between treatments were investigated by Tukey's test. The average values including the standard deviation of the mean were calculated for every examined parameter. Statistical analysis of viscosity, $\mathrm{pH}$ and foot pad lesion data were carried out using ANOVA and multiple comparisons between treatment means (Tukey's test) with the use of GraphPad Prism (version 9.1.2 for 
Windows ${ }^{\circledR}$, GraphPad Software, San Diego, CA, USA). The level of significance was set at $p<0.05$.

\section{Results}

\subsection{Enzyme Activity Recovery in Feed Samples}

The results corroborated that the new xylanase had been added correctly to the diets according to specifications in the trial protocol as presented in Table 4.

Table 4. Intended and measured xylanase enzyme activity in the different feed samples.

\begin{tabular}{cccc}
\hline Treatment & Phase & $\begin{array}{c}\text { Intended Xylanase } \\
\text { Activity }\end{array}$ & $\begin{array}{c}\text { Measured Xylanase } \\
\text { Activity }\end{array}$ \\
\hline \multirow{2}{*}{ Control } & Starter & $0 \mathrm{U} / \mathrm{kg}$ & $0 \mathrm{U} / \mathrm{kg}$ \\
& $\begin{array}{c}\text { Grower } \\
\text { Finisher }\end{array}$ & & \\
\hline \multirow{2}{*}{ T2 } & Starter & $30,000 \mathrm{U} / \mathrm{kg}$ & $27,675 \mathrm{U} / \mathrm{kg}$ \\
& Grower & & $35,479 \mathrm{U} / \mathrm{kg}$ \\
& Finisher & & $31,271 \mathrm{U} / \mathrm{kg}$ \\
\hline & Starter & $45,000 \mathrm{U} / \mathrm{kg}$ & $44,557 \mathrm{U} / \mathrm{kg}$ \\
& Grower & & $51,297 \mathrm{U} / \mathrm{kg}$ \\
& Finisher & & $41,104 \mathrm{U} / \mathrm{kg}$ \\
\hline & Starter & & $92,792 \mathrm{U} / \mathrm{kg}$ \\
& Grower & $90,000 \mathrm{U} / \mathrm{kg}$ & $84,059 \mathrm{U} / \mathrm{kg}$ \\
& Finisher & & $82,425 \mathrm{U} / \mathrm{kg}$ \\
\hline
\end{tabular}

\subsection{Visualization of Hydrolysis Products of Wheat Bran}

In Figure 2, it has been demonstrated that oligosaccharide size changes in response to xylanase inclusion. Here, the predominance of XOS and AXOS as hydrolysis products was observed (Figure 2), which indicates that the xylanase internally cleaves the xylan molecules. Thereby, it releases oligosaccharides of xylose and arabinose as major products which could serve as catalyst for viscosity reduction in the intestinal tract.

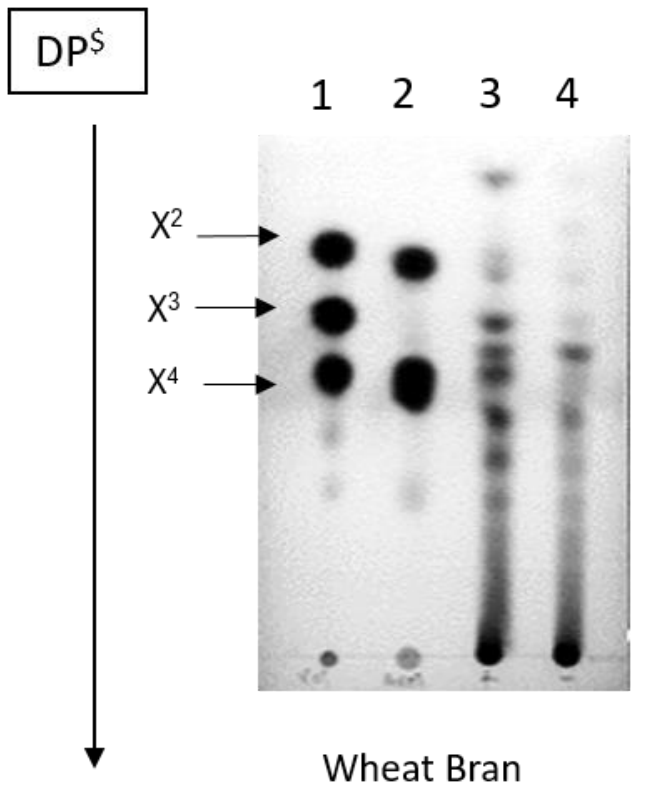

Figure 2. Thin layer chromatography of the hydrolysis products of beechwood xylan by the xylanase enzyme. After hydrolysis of wheat bran with the xylanase (Xygest HT), hydrolysates were developed on silica gel plate. Lane 1: XOS (X2-X4) standards, Lane 2: AXOS (A3X,XA3XX/XA2XX) standards, Lane 3: Control + Xygest HT, Lane 4: Control. Degrees of polymerization (DP $\left.{ }^{\$}\right)$. 


\subsection{Viscosity and $p H$ of Intestinal Digesta}

In the jejunum, there was a drop in viscosity of $35 \%$ for T4 compared to the control treatment $(p<0.05)$ (Figure 3). The lowest viscosity was noted in the T4 group, and the highest viscosity was observed in the T1 group. Also in the ileum, viscosity differences were statistically significant between groups as revealed by one-way ANOVA analysis $(p=0.05)$. Based on Tukey's post hoc test, there was a drop in viscosity of $18 \%$ for T2, $26 \%$ for T3 and 14\% for T4 compared to the control treatment.
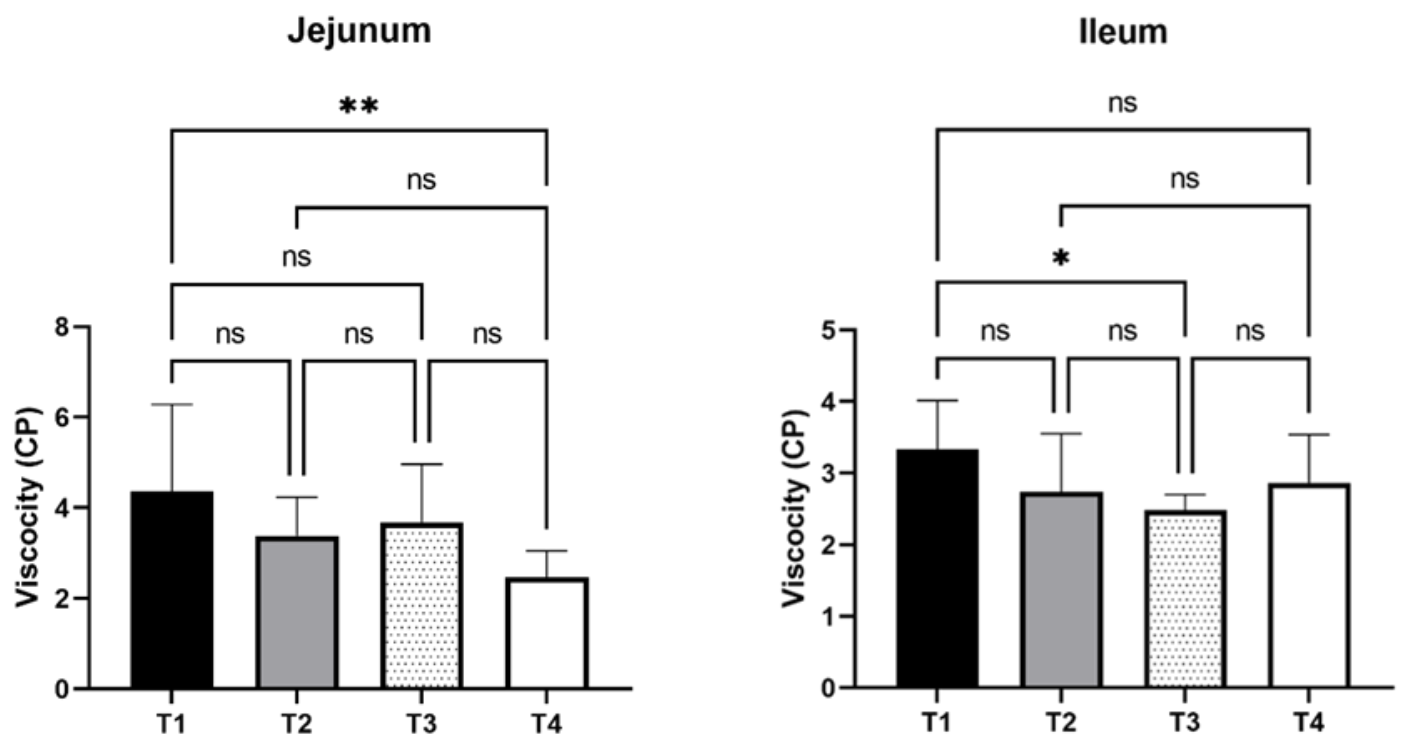

Figure 3. Effects of different levels of enzyme supplementation on viscosity in jejunum and ileum of broilers (mean $\pm \mathrm{SD}$ ) ( $\mathrm{n}=12$ /treatment). T1: control-no enzyme; T2: 30,000 U/kg enzyme activity; T3: 45,000 U/kg enzyme activity; T4: $90,000 \mathrm{U} / \mathrm{kg}$ enzyme activity. *: mean values differ significantly between them $(p<0.05) .{ }^{* *}$ : mean values differ significantly between them $(p<0.01)$. ns: not significant.

The $\mathrm{pH}$ measurements of intestinal content showed that the $\mathrm{pH}$ of the duodenum and cecum was not affected by dietary xylanase supplementation. However, in the jejunum, the T3 treatment reduced significantly the $\mathrm{pH}$ compared to the other treatments $(p<0.005)$. In the ileum, $\mathrm{T} 3$ group showed the lowest $\mathrm{pH}$ compared to the other treatment groups, while $\mathrm{T} 2$ and $\mathrm{T} 4$ groups also showed lower intestinal $\mathrm{pH}$ value compared to the control group, as shown in Figure 4.

\subsection{Performance}

The body weight (BW) at days 1, 7, 14, 21, 28, and 35 is shown in Table 5 . The birds of all animals treated with the new xylanase had increased BW at the end of the first week (day 7) compared to the counterparts $(p<0.05)$. On day 14 , birds of the T2 and T3 groups were heavier compared to birds of the control group $(0 \mathrm{U} / \mathrm{kg})(p<0.05)$. At the end of the experimental period birds of the T2 group were heavier compared to birds of the control group $(p<0.05)$. 
pH Duodenum

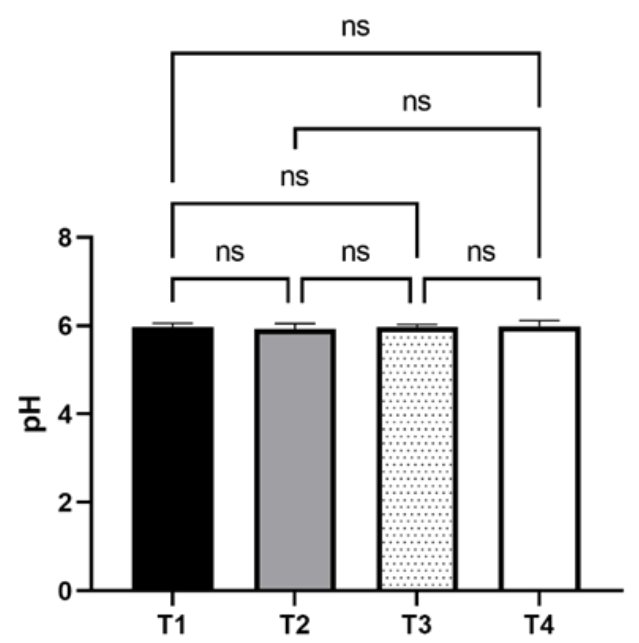

pH lleum



pH Jejunum
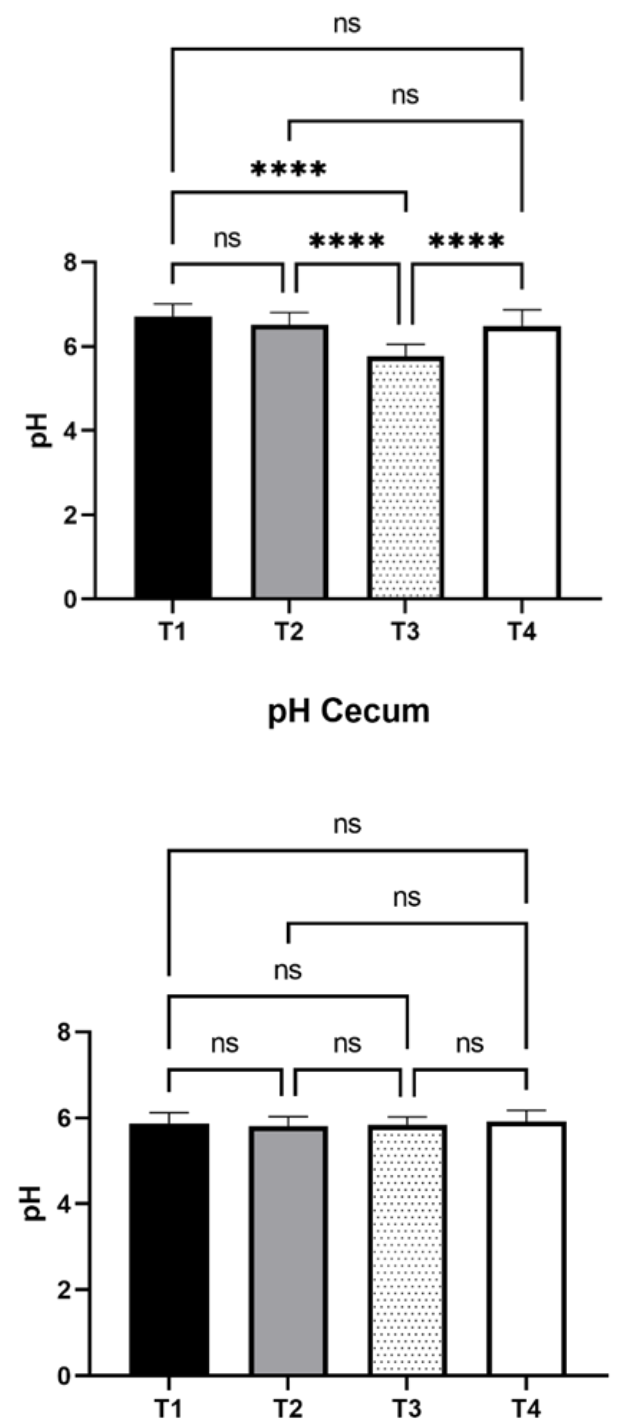

Figure 4. Effects of different levels of xylanase enzyme supplementation on intestinal content $\mathrm{pH}$ in duodenum, jejunum, ileum and cecum of broilers (mean $\pm \mathrm{SD})(n=12 /$ treatment). T1: control-no enzyme; T2: 30,000 U/kg enzyme activity; T3: 45,000 U/kg enzyme activity; T4: 90,000 U/kg enzyme activity. *: mean values differ significantly between them $(p<0.05)$. ${ }^{* *}$ : mean values differ significantly between them $(p<0.01){ }^{* * * *}$ : mean values differ significantly between them $(p<0.0001)$. ns: not significant.

Table 5. Effects of different levels of xylanase enzyme supplementation on body weight ( $\mathrm{g}$ ) of broilers at different growth stages (days $1,7,14,21,28$, and 35) ( $n=12 /$ treatment).

\begin{tabular}{ccccccc}
\hline \multirow{2}{*}{ Days } & \multicolumn{5}{c}{ Treatment } & \multirow{2}{*}{$\boldsymbol{p}$-Value } \\
\cline { 2 - 5 } & T1 & T2 & T3 & T4 & SEM & \\
\hline 1 & $44.5^{\mathrm{b}}$ & $44.4^{\mathrm{a}}$ & 44.4 & 44.1 & 0.27 & 0.544 \\
7 & $161.6^{\mathrm{b}}$ & $174.8^{\mathrm{a}}$ & $171.4^{\mathrm{a}}$ & $169.6^{\mathrm{a}}$ & 3.45 & 0.004 \\
14 & $402.5^{\mathrm{c}}$ & $434.3^{\mathrm{a}, \mathrm{b}}$ & $429.6^{\mathrm{a}, \mathrm{b}}$ & $414.9^{\mathrm{b}, \mathrm{c}}$ & 10.18 & 0.013 \\
21 & $803.3^{\mathrm{b}}$ & $859.3^{\mathrm{a}}$ & 836.4 & 839.7 & 26.62 & 0.221 \\
28 & $1281.5^{\mathrm{b}}$ & $1348.7^{\mathrm{a}}$ & $1325.2^{\mathrm{a}, \mathrm{b}}$ & $1285.8^{\mathrm{b}}$ & 25.58 & 0.033 \\
35 & $1913.6^{\mathrm{b}}$ & $2039.3^{\mathrm{a}}$ & $1984.5^{\mathrm{a}, \mathrm{b}}$ & $1933.5^{\mathrm{b}}$ & 41.02 & 0.017 \\
\hline
\end{tabular}

T1: control-no enzyme; T2: 30,000 U/kg enzyme activity; T3: 45,000 U/kg enzyme activity; T4: 90,000 U/kg enzyme activity. Body weight $=\mathrm{BW}$. Values are means. $\mathrm{SEM}=$ standard error of the mean. ${ }^{\mathrm{a}, \mathrm{b}, \mathrm{c}}$ Means within the same row with different superscripts are significantly different at $p<0.05$. 
The BWG of birds in all experimental groups during each week, as well as during the 1-14, 15-28, 29-35, and 1-35-day periods is shown in Table 6. For the 1-7-day period all treatment groups supplemented with the new xylanase exhibited higher BWG compared to birds in the control group $(p<0.05)$. During the period between days 8-14 and days $1-14$, the highest value of BWG was observed in birds fed either 30,000 U/kg (T2) or $45,000 \mathrm{U} / \mathrm{kg}$ (T3) xylanase compared to those from the control group $(p<0.05)$. For the whole experimental period, broilers supplemented with the lowest dose (T2) had higher BWG compared to those of the control group and to T4 group $(p<0.05)$.

Table 6. Effects of different levels of xylanase enzyme supplementation on average daily gain (g/day) of broilers at different growth periods (days 1-7, 8-14, 15-21, 22-28) ( $n=12$ /treatment).

\begin{tabular}{|c|c|c|c|c|c|c|}
\hline \multirow{2}{*}{ Days } & \multicolumn{5}{|c|}{ Treatment } & \multirow{2}{*}{$p$-Value } \\
\hline & T1 & T2 & T3 & T4 & SEM & \\
\hline $1-7$ & $16.7^{\mathrm{b}}$ & $18.6^{\mathrm{a}}$ & $18.2^{\mathrm{a}}$ & $17.9^{a}$ & 0.48 & 0.003 \\
\hline 8-14 & $34.4^{c}$ & $37.1^{a, b}$ & $36.9^{a, b}$ & $35.0^{b, c}$ & 1.10 & 0.044 \\
\hline $15-21$ & 57.3 & 60.7 & 58.1 & 60.7 & 3.06 & 0.571 \\
\hline $22-28$ & 68.3 & 69.9 & 69.8 & 63.7 & 3.16 & 0.184 \\
\hline $29-35$ & 90.3 & 98.7 & 94.2 & 92.5 & 3.82 & 0.178 \\
\hline $1-14$ & $25.64^{c}$ & $27.9^{a, b}$ & $27.5^{\mathrm{a}, \mathrm{b}}$ & $26.5^{b, c}$ & 0.72 & 0.011 \\
\hline $15-28$ & 62.8 & 65.3 & 64.0 & 62.2 & 1.51 & 0.191 \\
\hline $1-35$ & $53.4^{\mathrm{b}}$ & $57.0^{\mathrm{a}}$ & $55.4^{\mathrm{a}, \mathrm{b}}$ & $54.0^{\mathrm{b}}$ & 3.82 & 0.017 \\
\hline
\end{tabular}

T1: control-no enzyme; T2: 30,000 U/kg enzyme activity; T3: 45,000 U/kg enzyme activity; T4: 90,000 U/kg enzyme activity. Average daily gain = BWG. Values are means. SEM = standard error of the mean. ${ }^{a, b, c}$ Means within the same row with different superscripts are significantly different at $p<0.05$.

The ADFI of birds in all experimental groups during each week, as well as during the 1-14, 15-28, and 1-35-day periods is shown in Table 7. The ADFI in birds supplemented with $30,000 \mathrm{U} / \mathrm{kg}$ xyalanse was higher only during the period 29-35 days of age compared to birds supplemented with either 0 or $90,000 \mathrm{U} / \mathrm{kg}(p<0.05)$. No other significant difference was detected for ADFI between treatments.

Table 7. Effects of different levels of xylanase enzyme supplementation on average daily feed intake (g/day) of broilers at different growth periods (days 1-7, 8-14, 15-21, 22-28, 29-35 and 1-14, 15-28, 1-35) ( $n=12$ /treatment).

\begin{tabular}{ccccccc}
\hline \multirow{2}{*}{ Days } & \multicolumn{5}{c}{ Treatment } & p-Value \\
\cline { 2 - 5 } & T1 & T2 & T3 & T4 & SEM & \\
\hline $1-7$ & 21.9 & 22.1 & 22.7 & 22.3 & 1.24 & 0.916 \\
$8-14$ & 55.0 & 52.2 & 53.5 & 54.5 & 1.71 & 0.386 \\
$15-21$ & 83.0 & 83.0 & 83.6 & 82.0 & 5.05 & 0.991 \\
$22-28$ & 105.9 & 108.3 & 105.4 & 102.2 & 2.32 & 0.083 \\
$29-35$ & $155.4^{\mathrm{b}}$ & $163.1^{\mathrm{a}}$ & $158.2^{\mathrm{a}, \mathrm{b}}$ & $151.2^{\mathrm{b}}$ & 3.38 & 0.009 \\
$1-14$ & 38.4 & 37.1 & 38.1 & 38.4 & 0.67 & 0.203 \\
$15-28$ & 94.5 & 95.7 & 94.5 & 92.1 & 2.78 & 0.628 \\
$1-35$ & 84.2 & 85.7 & 84.7 & 82.4 & 3.38 & 0.009 \\
\hline
\end{tabular}

T1: control-no enzyme; T2: 30,000 U/kg enzyme activity; T3: 45,000 U/kg enzyme activity; T4: 90,000 U/kg enzyme activity. Average daily feed intake = ADFI. Values are means. SEM = standard error of the mean. a,b Means within the same row with different superscripts are significantly different at $p<0.05$.

The FCR of birds in all experimental groups during each week, as well as during the 1-14, 15-28, and 1-35 days periods is shown in Table 8. FCR was lowest in birds supplemented with 30,000 and 45,000 U/ kg xylanase during the 8-14 days period and for the 1-14 days period ( $p<0.05$ ). Regarding the total experimental period (days 1-35), broilers that were fed diets supplemented with the tested product irrespective of the dose had significantly lower FCR compared to those of the control group $(p<0.05)$. 
Table 8. Effects of different levels of xylanase enzyme supplementation on feed conversion ratio of broilers at different growth periods (days 1-7, 8-14, 15-21, 22-28, 29-35 and 1-14, 15-28, 1-35) ( $n=12 /$ treatment).

\begin{tabular}{ccccccc}
\hline \multirow{2}{*}{ Days } & \multicolumn{5}{c}{ Treatment } & p-Value \\
\cline { 2 - 6 } & T1 & T2 & T3 & T4 & SEM & \\
\hline $1-7$ & 1.35 & 1.21 & 1.30 & 1.27 & 0.06 & 0.134 \\
$8-14$ & $1.58^{\mathrm{a}}$ & $1.42^{\mathrm{c}}$ & $1.44^{\mathrm{b}, \mathrm{c}}$ & $1.56^{\mathrm{a}, \mathrm{b}}$ & 0.07 & 0.032 \\
$15-21$ & 1.48 & 1.39 & 1.44 & 1.42 & 0.09 & 0.775 \\
$22-28$ & 1.57 & 1.56 & 1.51 & 1.73 & 0.16 & 0.590 \\
$29-35$ & 1.78 & 1.70 & 1.69 & 1.64 & 0.06 & 0.153 \\
$1-14$ & $1.51^{\mathrm{a}}$ & $1.34^{\mathrm{c}}$ & $1.40^{\mathrm{b}, \mathrm{c}}$ & $1.46^{\mathrm{a}, \mathrm{b}}$ & 0.04 & 0.001 \\
$15-28$ & 1.56 & 1.50 & $1.46^{\mathrm{b}}$ & 1.52 & 0.04 & 0.307 \\
$1-35$ & $1.62^{\mathrm{a}}$ & $1.54^{\mathrm{b}}$ & $1.53^{\mathrm{b}}$ & $1.55^{\mathrm{b}}$ & 0.03 & 0.014 \\
\hline
\end{tabular}

T1: control-no enzyme; T2: 30,000 U/kg enzyme activity; T3: 45,000 U/kg enzyme activity; T4: 90,000 U/kg enzyme activity. Feed conversion ratio $=$ FCR. Values are means. SEM $=$ standard error of the mean. ${ }^{a, b, c}$ Means within the same row with different superscripts are significantly different at $p<0.05$.

With regards to mortality, during the experimental period dead broilers per treatment group were: 9 for control, 10 for $30,000 \mathrm{U} / \mathrm{kg}$, 1 for $45,000 \mathrm{U} / \mathrm{kg}$, and 9 for $90,000 \mathrm{U} / \mathrm{kg}$. No significant difference was found between treatments for the number of dead birds $(p=0.4)$.

\subsection{Carcass Measurements and Internal Organ Weights}

The average values of carcass measurements and internal organ weights are shown in Table 9. Interestingly, live weight and carcass weight of sampled birds was significantly higher in the treatments supplemented with 45,000 and 90,000 $\mathrm{U} / \mathrm{kg}$ xylanase compared to the control group $(p<0.05)$. Similar significant differences were observed for the legs and liver weight $(p<0.05)$. Similar significant differences were observed for the legs and liver weight $(p<0.05)$. The weight of kidneys was significantly higher in the treatment supplemented with 90,000 U/ kg xylanase compared to the control group and the group supplemented with $30,000 \mathrm{U} / \mathrm{kg}$ xylanase $(p<0.05)$.

Table 9. Effects of different levels of xylanase enzyme supplementation on carcass measurements and absolute internal organ weights of broilers. $n=24$ for live weight, carcass weight, breast, legs, liver, heart, gizzard, and intestine; $n=12$ for kidneys, bursa of Fabricius, spleen, and thymus.

\begin{tabular}{ccccccc}
\hline \multirow{2}{*}{ Parameter } & \multicolumn{5}{c}{ Treatment } & p-Value \\
\cline { 2 - 5 } & T1 & T2 & T3 & T4 & SEM & \\
\hline Live weight (g) & $2061.8^{\mathrm{b}}$ & $2122.7^{\mathrm{ab}}$ & $2268.9^{\mathrm{a}}$ & $2300.2^{\mathrm{a}}$ & 93.75 & 0.035 \\
Carcass weight (g) & $1841.6^{\mathrm{b}}$ & $1904.8^{\mathrm{ab}}$ & $2044.6^{\mathrm{a}}$ & $2066.0^{\mathrm{a}}$ & 85.84 & 0.027 \\
Breast (g) & $569.4^{\mathrm{b}}$ & $560.8^{\mathrm{b}}$ & 624.4 & $641.7^{\mathrm{a}}$ & 35.06 & 0.057 \\
Legs (g) & $400.8^{\mathrm{b}}$ & $430.4^{\mathrm{ab}}$ & $455.8^{\mathrm{a}}$ & $449.5^{\mathrm{a}}$ & 19.14 & 0.023 \\
Liver (g) & $46.3^{\mathrm{b}}$ & $51.9^{\mathrm{ab}}$ & $51.3^{\mathrm{a}}$ & $52.0^{\mathrm{a}}$ & 2.65 & 0.097 \\
Heart (g) & 12.3 & 13.2 & 13.2 & 13.3 & 0.62 & 0.373 \\
Gizzard (g) & 78.1 & 80.7 & 80.5 & 78.3 & 2.67 & 0.648 \\
Intestine (g) & 173.0 & 169.1 & 177.2 & 181.4 & 11.46 & 0.733 \\
Kidneys (g) & $11.8^{\mathrm{b}}$ & $11.7^{\mathrm{b}}$ & $13.1^{\mathrm{ab}}$ & $14.0^{\mathrm{a}}$ & 0.86 & 0.025 \\
Bursa of Fabricius (g) & $4.6^{\mathrm{b}}$ & 4.2 & 4.9 & 4.7 & 0.49 & 0.496 \\
Spleen (g) & 2.2 & 1.9 & 2.5 & 2.4 & 0.27 & 0.175 \\
Thymus (g) & 3.9 & 3.7 & 4.5 & 4.8 & 0.61 & 0.269 \\
\hline
\end{tabular}

T1: control-no enzyme; T2: 30,000 U/kg enzyme activity; T3: 45,000 U/kg enzyme activity; T4: 90,000 U/kg enzyme activity. Values are means $\pm \mathrm{SD}$. ${ }^{\mathrm{a}, \mathrm{b}}$ Means within the same row with different superscripts are significantly different at $p<0.05$.

\subsection{Foot Pad Lesion Scoring}

The evaluation of foot pad lesions showed no significant effect of xylanase supplementation on foot pad dermatitis score, as shown in Figure 5. 

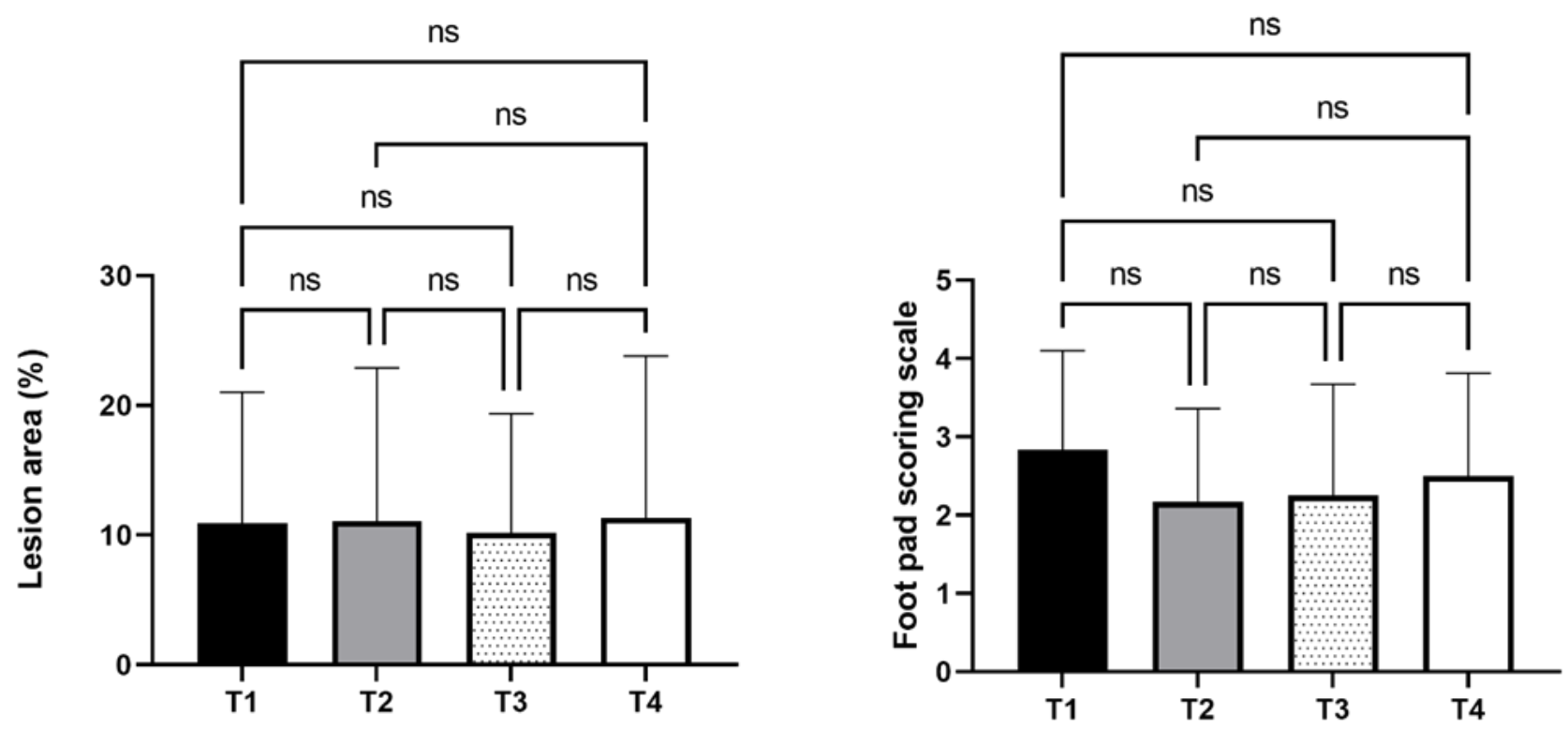

Figure 5. Effects of different levels of xylanase enzyme supplementation on foot pad lesion area and foot pad scoring in broilers (mean $\pm \mathrm{SD}$ ). T1: control-no enzyme; T2: 30,000 U/kg enzyme activity; T3: 45,000 U/kg enzyme activity; T4: 90,000 $\mathrm{U} / \mathrm{kg}$ enzyme activity. ns: not significant ( $n=12$ broilers per treatment).

\section{Discussion}

The increased content of NSP in broiler diets exerts anti-nutritive effects by increasing digesta viscosity, mainly by the fraction of soluble NSP [30]. Cereals have cell walls that contain up to $15 \%$ NSPs, which include soluble and insoluble NSPs [31]. NSPases have been reported to breakdown NSP present within the intact cell wall. Such rupture of the cell wall may increase the digestibility of physically entrapped nutrients $[18,31]$. The insoluble fraction of NSPs makes up the bulk of the total fiber in diets, and they are considered as a nutrient dilution factor and have little or no effect on nutrient utilization in monogastric animals [32,33]. However, the soluble fractions of NSPs, mainly arabinoxylans in wheat, act as a physical barricade to nutrient digestion and absorption by increasing gut viscosity [13].

For the present study, we explored the impact of a new, intrinsically thermostable, mono-component xylanase in wheat-based broiler diets. For this reason, high NSP diets were formulated to provide sufficient substate for the xylanase to act. The NSP levels were similar or higher than those reported in research studies evaluating the efficacy of xylanases in wheat-based diets [30]. Compared to the control diets, the tested xylanase decreased viscosity and $\mathrm{pH}$ at various intestinal segments, improved broiler performance and was beneficial for the carcass traits. It is essential to stabilizing the physico-chemical characteristics of the gut content especially in the case of high viscosity diets, using digestibility enhancers.

In previous studies, xylanase supplementation resulted in a reduction of intestinal viscosity in broilers aged 14 or 28 days when fed high rye diets [34]. This reduction in intestinal viscosity is associated with enhanced intestinal digestion and absorption. Kouzounis et al. (2021) [30] showed that xylanase supplementation in wheat-based diets in broilers improved nutrient digestibility and arabinoxylan fermentability. Barekatain et al. (2013) [35] reported that addition of xylanase to diets containing sorghum distillers' dried grains with soluble (sDDGS) significantly lowered the concentration of insoluble NSPs and augmented the concentration of free sugars (arabinose and xylose) in the ileal digesta. That study explained that the availability of these free sugars may have provided nutrients to the birds, leading to improved FCR. This research implies that the beneficial effects of xylanase are primarily through the reduction in the viscosity and, secondarily, the release of sugars [24,36]. The release of monosaccharides by exogenous enzymes is through two mechanisms: firstly, the breakdown of NSPs deliberates monosaccharides, and secondly, 
the breakdown of NSPs releases the starch within the endosperm, which exposes the starch to the endogenous amylase, releasing more glucose.

With regards to intestinal $\mathrm{pH}$, previous studies in broilers fed with wheat-based diets, showed that xylanase supplementation may affect differently gastrointestinal tract's $\mathrm{pH}$. In the study of Esmaeilipour et al. (2012) [37] xylanase did not affect pH in any part of the gastrointestinal tract. Elsewhere, Engberg et al. (2004) [38] showed that in broilers fed diets with different forms of wheat, xylanase resulted in a reduction of $\mathrm{pH}$ in duodenum, jejunum, and cecum. Gao et al. (2008) [23], reported that xylanase caused a reduction of $\mathrm{pH}$ value only in cecum, while $\mathrm{pH}$ value increased in duodenum, jejunum, and ileum. Our results showed that $\mathrm{pH}$ reduction due to xylanase supplementation occurred mainly at the site of jejunum and ileum, which are the two main sites of nutrient digestion and absorption. It has been suggested that a decrease in intestinal $\mathrm{pH}$ increases pancreatic secretion of digestive enzymes and the segregation of bile acid for lipid emulsification, which improves digestion and absorption of nutrients [39,40]. It should also be noted that the greatest reduction in $\mathrm{pH}$ was achieved by the $45,000 \mathrm{U} / \mathrm{kg}$ level of supplementation, while the double dose did not result in any further improvement. The observed effects of xylanase on jejunum and ileum $\mathrm{pH}$ coincide with previous studies and could be attributed to an indirect effect on intestinal microbiota. Engberg et al. (2004) [38] showed that xylanase supplementation increased the concentration of lactic acid in ileal contents. Lactic acid production could be related with abundance of beneficial gut microbiota such as Lactobacillus spp. Indeed, recently was shown that xylanase supplementation increased the abundance of Ruminococcaceae, Lachnospiraceae, and Lactobacillus salivarius [41]. The latter authors suggested that xylanase supplementation promoted broiler performance by improving feed efficiency and that these effects may be related to the increased abundance of beneficial gut microbiota [41]. A recent study [31] showed that supplementation of the same enzyme as in the current study in corn-based diets, stimulated Lactobacilli growth. Thus, it can be hypothesized that the $\mathrm{pH}$ reduction observed in the current study was mediated by a similar mechanism. However, further investigation is required to clarify these effects in wheat-based diets.

An interesting finding in this study is that supplementation of the enzyme improved broiler growth at their early life stage (period between days $1-7,1-14$, and $8-14$ ). It is known that broiler chicks do not have a well-developed gastrointestinal tract. During the starter phase, broiler chicks cannot efficiently utilize high levels of fiber in the diet and as a result have impaired growth during the first week [42]. Other studies also showed improved body weight and FCR in young chickens after dietary supplementation with exogenous enzymes [43]. Similarly, Santos et al. (2013) [44] showed beneficial growth performance results when xylanase was used as a supplement in rye-based diets for broiler chickens in their early growth stages up to 21 days of life. In the present study, a significant effect was observed on FCR in early growth stages (8-14 days, 1-14 days) in the $30,000 \mathrm{U} / \mathrm{kg}$ group. Van Hoeck et al. [27] showed that the supplementation of the same xylanase in corn-based diet significantly improved FCR for the overall study period. The latter study demonstrated also an overall beneficial effect of xylanase, even at 30,000 U/ kg, on broilers' performance and carcass traits. In accordance with other reports [23,26], the data of the present study once more confirmed that the addition of xylanase to wheat-based diets significantly increased the BWG and improved the FCR of broilers at 35 days of age. Munyaka et al. [45] showed increased body weight gain in broilers chickens fed wheat-based diets supplemented with xylanase. Lee et al. (2020) [46] reported that weight gain and feed conversion ratio during the overall study period responded linearly to higher levels of xylanase supplementation. Similar effects were also reported in earlier studies in which broilers' diets were wheat-based [37,47,48]. Thus, the significant effects observed herein regarding carcass parameters could be attributed to the effect of xylanase on BWG. Moreover, the greater weight of internal organs such as the liver and kidneys, may also be related to the greater metabolic needs in the xylanase supplemented groups. Liver growth is related to a higher metabolic rate and is associated with an increase in the small intestine 
weight, which stimulates the production of bile acid from the liver needed for the digestion of lipids $[40,49]$.

In this study, xylanase supplementation did not affect the FI of birds, indicating that the improvement in feed efficiency observed is likely to be a result of the improved nutrient utilization. Notably, all experimental groups supplemented with the new xylanase showed improved FCR compared to the control group. These effects could be attributed to an increased utilization of feed ingredients due to a more efficient breakdown of NSP contained in the feed [50,51]. Similarly, Lee et al. (2020) [46] showed improved digestibility of dry matter, gross energy, nitrogen, and soluble non-starch polysaccharides.

The evaluation of foot pad lesions showed no significant effect of xylanase supplementation on foot pad lesions. According to Shepherd et al. (2010) [52], increased concentrations of non-starch polysaccharides in broilers' diets may cause excreta that can adhere to the foot pads, most probably because of increased intestinal viscosity. Although there was an improvement in intestinal viscosity in the present study, this did not affect positively foot pad lesions. To our knowledge this is one of the few studies that has evaluated foot pad lesions in conjunction with xylanase supplementation in broilers. As foot pad dermatitis is a multifactorial condition, it is necessary to consider other potential interacting factors, besides NSP content of broiler diets. This field warrants further investigation.

\section{Conclusions}

Dietary supplementation of the new xylanase resulted in lower intestinal viscosity and lower $\mathrm{pH}$. Moreover, supplementation of the new xylanase at 30,000 $\mathrm{U} / \mathrm{kg}$ resulted in a significant improvement of broiler performance and carcass traits when feeding wheatbased diets. The latter effects were probably mediated by positive effects on nutrient digestibility. Nevertheless, digestibility of nutrients was not evaluated in the present study. Thus, a further evaluation of the effects of the tested xylanase in high-NSP diets is necessary.

Author Contributions: Conceptualization, V.V.H. and G.A.P.; methodology, G.A.P.; software, G.A.P.; validation, G.A.P., I.G (Ilias Giannenas).; formal analysis, I.G. (Ilias Giannenas), I.G. (Ioannis Grivas); V.T., S.L., T.M., and B.L.V.; investigation, G.A.P., I.G. (Ilias Giannenas), I.G. (Ioannis Grivas), V.T., S.L., T.M., P.F., and K.K.; resources, V.V.H., D.M.; data curation, G.A.P., S.L.; writing-original draft preparation, V.V.H., G.A.P., I.G. (Ilias Giannenas), and S.L.; writing—review and editing, V.V.H., G.A.P., A.L.G.S., and D.M.; visualization, S.L., I.G. (Ioannis Grivas); supervision, G.A.P.; project administration, V.V.H. and G.A.P.; funding acquisition, G.A.P. All authors have read and agreed to the published version of the manuscript.

Funding: This research was funded by Kemin Europa N.V., Research Project Code 99821 (Research Committee of Aristotle University of Thessaloniki, Greece).

Institutional Review Board Statement: The study was conducted according to the European directive 2010/63/EU on the protection of animals used for scientific purposes and was approved by the Research Committee of Aristotle University of Thessaloniki, Greece.

Informed Consent Statement: Not applicable.

Data Availability Statement: The data presented in this study are available within the article.

Conflicts of Interest: The funding source was not involved in the collection, analysis, or interpretation of data that were collected during the study. The funding source was involved in the writing of the manuscript. The decision to publish the results was mutually agreed between the University research team members and the funding source members.

\section{References}

1. Hahn-Didde, D.; Purdum, S.E. The effects of an enzyme complex in moderate and low nutrient-dense diets with dried distillers grains with solubles in laying hens. J. Appl. Poult. Res. 2014, 23, 23-33. [CrossRef]

2. Choct, M.; Annison, G. The inhibition of nutrient digestion by wheat pentosans. Br. J. Nutr. 1992, 67, 123-132. [CrossRef]

3. Choct, M.; Annison, G. Anti-nutritive effect of wheat pentosans in broiler chickens: Roles of viscosity and gut microflora. Br. Poult. Sci. 1992, 33, 821-834. [CrossRef] 
4. Friesen, O.; Guenter, W.; Marquardt, R.; Rotter, B. The Effect of Enzyme Supplementation on the Apparent Metabolizable Energy and Nutrient Digestibilities of Wheat, Barley, Oats, and Rye for the Young Broiler Chick. Poult. Sci. 1992, 71, 1710-1721. [CrossRef] [PubMed]

5. Bhat, M. Cellulases and related enzymes in biotechnology. Biotechnol. Adv. 2000, 18, 355-383. [CrossRef]

6. Bedford, M.R.; Classen, H.L. The Iinfluence of dietary xylanase on intestinal viscosity and molecular weight distribution of carbohydrates in rye-fed broiler chicks. Prog. Biotechnol. 2013, 7, 361-370.

7. Cowan, W.D. Animal feed. In Industrial Enzymology, 2nd ed.; Godfrey, T., West, S., Eds.; Macmillan Press: London, UK, 1996; pp. 360-371.

8. Galante, Y.M.; De Conti, A.; Monteverdi, R. Application of Trichoderma enzymes in food and feed industries. In Trichoderma $\mathcal{E}$ Gliocladium-Enzymes, Biological Control and Commercial Applications; Harman, G.F., Kubicek, C.P., Eds.; Taylor \& Francis: London, UK, 1998.

9. Krzysztof, Z.K.; Gogol, D.; Koreleski, J. Simultaneous application of phytase and xylanase to broiler feeds based on wheat: In vitro measurements of phosphorus and pentose release from wheat and wheat-based feeds. J. Sci. Food Agric. 1999, 79, 1832-1840. [CrossRef]

10. Bedford, M.; Morgan, A. The use of enzymes in poultry diets. World's Poult. Sci. J. 1996, 52, 61-68. [CrossRef]

11. Choct, M.; Hughes, R.J.; Wang, J.; Bedford, M.R.; Morgan, A.J.; Annison, G. Increased small intestinal fermentation is partly responsible for the anti-nutritive activity of non-starch polysaccharides in chickens. Br. Poult. Sci. 1996, 37, 609-621. [CrossRef]

12. Nian, F.; Guo, Y.M.; Ru, Y.J.; Li, F.D.; Peron, A. Effect of Exogenous Xylanase Supplementation on the Performance, Net Energy and Gut Microflora of Broiler Chickens Fed Wheat-based Diets. Asian-Australas. J. Anim. Sci. 2011, 24, 400-406. [CrossRef]

13. Choct, M.; Hughes, R.J.; Bedford, M.R. Effects of a xylanase on individual bird variation, starch digestion throughout the intestine, and ileal and caecal volatile fatty acid production in chickens fed wheat. Br. Poult. Sci. 1999, 40, 419-422. [CrossRef] [PubMed]

14. Mendes, A.R.; Ribeiro, T.; Correia, B.A.; Bule, P.; Maçãs, B.; Falcão, L.; Freire, J.P.B.; Ferreira, L.M.A.; Fontes, C.M.G.A.; Lordelo, M.M. Low doses of exogenous xylanase improve the nutritive value of triticale-based diets for broilers. J. Appl. Poult. Res. 2013, 22, 92-99. [CrossRef]

15. Bedford, M.; Partridge, G. Enzymes in Farm Animal Nutrition; CABI Publishing: Wallingford, UK, 2001.

16. Hesselman, K.; Elwinger, K.; Thomke, S. Influence of increasing levels of $\beta$-glucanase on the productive value of barley diets for broiler chickens. Anim. Feed. Sci. Technol. 1982, 7, 351-358. [CrossRef]

17. Rexen, B. Use of enzymes for improvement of feed. Anim. Feed. Sci. Technol. 1981, 6, 105-114. [CrossRef]

18. Walsh, G.A. Enzymes in the animal-feed industry. Trends Biotechnol. 1993, 11, 424-430. [CrossRef]

19. Li, Y.; Fang, Z.; Dai, J.; Partridge, G.; Ru, Y.; Peng, J. Corn extrusion and enzyme addition improves digestibility of corn/soy based diets by pigs: In vitro and in vivo studies. Anim. Feed. Sci. Technol. 2010, 158, 146-154. [CrossRef]

20. Mehri, M.; Shirmohammad, F. Effects of dietary supplementation of multi-enzyme complex on the energy utilisation in rooster and performance of broiler chicks. Afr. J. Biotechnol. 2011, 10, 7541-7547.

21. Glamocic, D.; Polovinski-Horvatovic, M.; Ivkovic, M.; Beukovic, D.; Bjedov, S. Effects of enzymes supplementation on digestibility and energy utilizations of broilers diets with different metabolizable energy level. Biotehnol. Stocarstou 2011, 27, 583-590. [CrossRef]

22. Choct, M.; Kocher, A.; Waters, D.; Pettersson, D.; Ross, G. A comparison of three xylanases on the nutritive value of two wheats for broiler chickens. Br. J. Nutr. 2004, 92, 53-61. [CrossRef]

23. Gao, F.; Jiang, Y.; Zhou, G.; Han, Z. The effects of xylanase supplementation on performance, characteristics of the gastrointestinal tract, blood parameters and gut microflora in broilers fed on wheat-based diets. Anim. Feed. Sci. Technol. 2008, 142, 173-184. [CrossRef]

24. Vandeplas, S.; Dauphin, R.D.; Thonart, P.; Théwis, A.; Beckers, Y. Effect of the bacterial or fungal origin of exogenous xylanases supplemented to a wheat-based diet on performance of broiler chickens and nutrient digestibility of the diet. Can. J. Anim. Sci. 2010, 90, 221-228. [CrossRef]

25. Vandeplas, S.; Dauphin, R.D.; Thiry, C.; Beckers, Y.; Welling, G.W.; Thonart, P.; Théwis, A. Efficiency of a Lactobacillus plantarumxylanase combination on growth performances, microflora populations, and nutrient digestibilities of broilers infected with Salmonella Typhimurium. Poult. Sci. 2009, 88, 1643-1654. [CrossRef] [PubMed]

26. Liu, D.; Guo, S.; Guo, Y. Xylanase supplementation to a wheat-based diet alleviated the intestinal mucosal barrier impairment of broiler chickens challenged byClostridium perfringens. Avian Pathol. 2012, 41, 291-298. [CrossRef] [PubMed]

27. Van Hoeck, V.; Wu, D.; Somers, I.; Wealleans, A.; Vasanthakumari, B.L.; Sanchez, A.L.G.; Morisset, D. Xylanase impact beyond performance: A prebiotic approach in broiler chickens. J. Appl. Poult. Res. 2021, 30, 100193. [CrossRef]

28. Kaukonen, E.; Norring, M.; Valros, A. Effect of litter quality on foot pad dermatitis, hock burns and breast blisters in broiler breeders during the production period. Avian Pathol. 2016, 45, 667-673. [CrossRef]

29. Schneider, C.A.; Rasband, W.S.; Eliceiri, K.W. NIH Image to ImageJ: 25 Years of image analysis. Nat. Methods 2012, 9, 671-675. [CrossRef] [PubMed]

30. Kouzounis, D.; Hageman, J.; Soares, N.; Michiels, J.; Schols, H. Impact of Xylanase and Glucanase on Oligosaccharide Formation, Carbohydrate Fermentation Patterns, and Nutrient Utilization in the Gastrointestinal Tract of Broilers. Animals 2021, $11,1285$. [CrossRef] 
31. Diebold, G.; Mosenthin, R.; Piepho, H.-P.; Sauer, W.C. Effect of supplementation of xylanase and phospholipase to a wheat-based diet for weanling pigs on nutrient digestibility and concentrations of microbial metabolites in ileal digesta and feces. J. Anim. Sci. 2004, 82, 2647-2656. [CrossRef]

32. Choct, M. Feed non-starch polysaccharides: Chemical structures and nutritional significance. Feed Milling Int. 1997, 191, 13-26.

33. Hetland, H.; Choct, M.; Svihus, B. Role of insoluble non-starch polysaccharides in poultry nutrition. World Poult. Sci. J. 2004, 60, 415-422. [CrossRef]

34. Dänicke, S.; Simon, O.; Jeroch, H.; Bedford, M. Interactions between dietary fat type and xylanase supplementation when rye-based diets are fed to broiler chickens 2 . Performance, nutrient digestibility and the fat-soluble vitamin status of livers. Br. Poult. Sci. 1997, 38, 546-556. [CrossRef] [PubMed]

35. Barekatain, M.; Antipatis, C.; Choct, M.; Iji, P. Interaction between protease and xylanase in broiler chicken diets containing sorghum distillers' dried grains with solubles. Anim. Feed. Sci. Technol. 2013, 182, 71-81. [CrossRef]

36. Malathi, V.; Devegowda, G. In Vitro Evaluation of Nonstarch Polysaccharide Digestibility of Feed Ingredients by Enzymes. Poult. Sci. 2001, 80, 302-305. [CrossRef]

37. Esmaeilipour, O.; Moravej, H.; Shivazad, M.; Rezaian, M.; Aminzadeh, S.; Van Krimpen, M. Effects of diet acidification and xylanase supplementation on performance, nutrient digestibility, duodenal histology and gut microflora of broilers fed wheat based diet. Br. Poult. Sci. 2012, 53, 235-244. [CrossRef]

38. Engberg, R.M.; Hedemann, M.S.; Steenfeldt, S.; Jensen, B.B. Influence of Whole Wheat and Xylanase on Broiler Performance and Microbial Composition and Activity in the Digestive Tract. Poult. Sci. 2004, 83, 925-938. [CrossRef] [PubMed]

39. Panda, A.K.; Rao, S.V.R.; Raju, M.; Sunder, G.S. Effect of Butyric Acid on Performance, Gastrointestinal Tract Health and Carcass Characteristics in Broiler Chickens. Asian-Australas. J. Anim. Sci. 2009, 22, 1026-1031. [CrossRef]

40. Martínez, Y.; Gonzalez, A.; Botello, A.; Perez, K. Effect of a Combination of Propionic-Acetic Acid on Body Weight, Relative Weight of Some Organs, Lactic Acid Bacteria and Intestinal pH of Neonatal Broilers. Braz. J. Poult. Sci. 2021, 23. [CrossRef]

41. Singh, A.K.; Mishra, B.; Bedford, M.R.; Jha, R. Effects of supplemental xylanase and xylooligosaccharides on production performance and gut health variables of broiler chickens. J. Anim. Sci. Biotechnol. 2021, 12, 98. [CrossRef] [PubMed]

42. Singh, A.; Berrocoso, J.D.; Dersjant-Li, Y.; Awati, A.; Jha, R. Effect of a combination of xylanase, amylase and protease on growth performance of broilers fed low and high fiber diets. Anim. Feed. Sci. Technol. 2017, 232, 16-20. [CrossRef]

43. Arczewska-Wlosek, A.; Swiatkiewicz, S.; Bederska-Lojewska, D.; Orczewska-Dudek, S.; Szczurek, W.; Boros, D.; Fras, A.; Tomaszewska, E.; Dobrowolski, P.; Muszynski, S.; et al. The Efficiency of Xylanase in Broiler Chickens Fed with Increasing Dietary Levels of Rye. Animals 2019, 9, 46. [CrossRef]

44. Santos, C.; Ribeiro, T.; Ponte, P.; Fernandes, V.; Falcão, L.; Freire, J.; Prates, J.; Ferreira, L.; Fontes, C.; Lordelo, M. The effects of restricting enzyme supplementation in rye-based diets for broilers. Anim. Feed. Sci. Technol. 2013, 186, 214-217. [CrossRef]

45. Munyaka, P.M.; Nandha, N.K.; Kiarie, E.; Nyachoti, C.M.; Khafipour, E. Impact of combined $\beta$-glucanase and xylanase enzymes on growth performance, nutrients utilization and gut microbiota in broiler chickens fed corn or wheat-based diets. Poult. Sci. 2016, 95, 528-540. [CrossRef]

46. Lee, S.H.; Hosseindoust, A.; Ingale, S.L.; Rathi, P.C.; Yoon, S.Y.; Choi, J.W.; Kim, J.S. Thermostable xylanase derived fromTrichoderma citrinovirideincreases growth performance and non-starch polysaccharide degradation in broiler chickens. Br. Poult. Sci. 2020, 61, 57-62. [CrossRef] [PubMed]

47. Francesch, M.; Pérez-Vendrell, A.; Broz, J. Effects of a mono-component endo-xylanase supplementation on the nutritive value of wheat-based broiler diets. Br. Poult. Sci. 2012, 53, 809-816. [CrossRef] [PubMed]

48. Cowieson, A.; O’Neill, H.M.; O’Neill, H.M. Effects of exogenous xylanase on performance, nutrient digestibility and caecal thermal profiles of broilers given wheat-based diets. Br. Poult. Sci. 2013, 54, 346-354. [CrossRef] [PubMed]

49. Adil, S.; Banday, T.; Bhat, G.A.; Mir, M.S.; Rehman, M. Effect of Dietary Supplementation of Organic Acids on Performance, Intestinal Histomorphology, and Serum Biochemistry of Broiler Chicken. Veter Med. Int. 2010, 2010, 479485. [CrossRef] [PubMed]

50. Co, F.G.P.; Goulart, C.; Figueiredo, D.; Oliveira, C.; Da Silva, J.H.V. Economic and Environmental Impact of Using Exogenous Enzymes on Poultry Feeding. Int. J. Poult. Sci. 2008, 7, 311-314. [CrossRef]

51. Buchanan, N.P.; Kimbler, L.B.; Parsons, A.S.; Seidel, G.E.; Bryan, W.B.; Felton, E.E.D.; Moritz, J.S. The Effects of Nonstarch Polysaccharide Enzyme Addition and Dietary Energy Restriction on Performance and Carcass Quality of Organic Broiler Chickens. J. Appl. Poult. Res. 2007, 16, 1-12. [CrossRef]

52. Shepherd, E.; Fairchild, B. Footpad dermatitis in poultry. Poult. Sci. 2010, 89, 2043-2051. [CrossRef] 